\title{
FIMICOLOUS HISTERIDAE COLEOPTERA IN CAMPO GRANDE, MS, BRAZIL
}

\author{
KOLLER, W. W., ${ }^{1}$ GOMES, A. ${ }^{1}$ and RODRIGUES, S. R. ${ }^{2}$ \\ ${ }^{1}$ Embrapa Gado de Corte, BR 262, km 4, C.P. 154, CEP 79002-970, Campo Grande, MS, Brazil \\ ${ }^{2}$ Universidade Estadual de Mato Grosso do Sul, Rodovia Aquidauana-Cera, km 12, \\ CEP 79200-000, Aquidauana, MS, Brazil \\ Correspondence to: Wilson Werner Koller, Embrapa Gado de Corte, C.P. 154, \\ CEP 79002-970, Campo Grande, MS, Brazil, e-mail: koller@cnpgc.embrapa.br \\ Received December 12, 2000 - Accepted April 17, 2001 - Distributed August 31, 2002
}

(With 1 figure)

\begin{abstract}
Fecal masses recently excreted and/or almost dry were collected weekly in a pasture of Brachiaria decumbens Stapf, from May 1990 to April 1992. The feces were conditioned in 15-liter opaque plastic buckets, containing lateral and top openings, where flasks were fastened for capturing Histeridae beetles present in these masses. Three thousand two hundred ninety-nine specimens were collected belonging to 11 species in the Genus: Phelister, Hister, Euspilotus, Acritus, and Xerosaprinus. The most frequent, constant, and abundant species were Phelister sp. nr. carinifrons and P. haemorrhous.
\end{abstract}

Key words: coleopterans fimicolous, Histeridae, bovine feces.

\section{RESUMO}

\section{Coleoptera Histeridae fimícolas de Campo Grande, MS, Brasil}

Massas fecais recém-excretadas até quase secas foram coletadas semanalmente em uma pastagem de Brachiaria decumbens Stapf, no período de maio de 1990 a abril de 1992. As fezes foram acondicionadas em baldes plásticos opacos com capacidade para 15 litros, contendo aberturas lateral e no topo, onde foram fixados frascos para a captura dos besouros histerídeos presentes nas massas fecais. Foram coletados 3.299 exemplares, pertencendo a 11 espécies dos gêneros: Phelister, Hister, Euspilotus, Acritus e Xerosaprinus. As espécies mais freqüentes, constantes e abundantes foram Phelister sp. nr. carinifrons e P. haemorrhous.

Palavras-chave: coleópteros fimícolas, Histeridae, fezes bovinas.

\section{INTRODUCTION}

The action of parasites constitutes one of the factors negatively affecting the productivity and the efficiency of livestock industrialization. Some of the principal bovine parasites, such as the horn fly (Haematobia irritans L., 1758) and several species of gastrointestinal helminthes, grow in the feces of the host and/or have their free-life phase associated with these feces. Several species of flies characterized as important mechanical and biological vectors of pathogenic organisms for man and domestic animals also grows in bovine feces
(Greenberg, 1971; Linhares, 1981; Lomônaco \& Almeida, 1995). Flies like these represent a public health problem.

The systematic control of bovine parasites by chemical pesticides can result in the emergence of resistant populations (Bull et al., 1988; McKenzie \& Byford, 1993; Cilek et al., 1995; Sheppard, 1995; Zizak et al., 1996) contributing to gradual loss of effectiveness of these products and elevation of pest control costs (Axtell, 1986).

In the fauna associated with bovine feces exist a great diversity of organisms. Among these, some aid regulating populations of other present arthro- 
pods; some who compete for food (feces); and still others that functioning as predators, parasites, or parasitoids.

The coleopterans of the Histeridae family are predators, as much in the young as in the adult phase. They prey on insects or small animals present in any substratum in decomposition (Arnett Jr., 1968). Geden \& Axtell (1988) studied some species of Histeridae with a view to determining of the potential control that they exercise on the population of the domestic fly, Musca domestica. Summerlin et al. (1991), and Fincher (1995) studied various species that act as predators of $H$. irritans.

In Australia, from 1969 to 1984,57 species of coprophagous coleopterans and histerids were introduced. Thirty-nine were created in laboratory and liberated in the field, and 26 of them settled down in the continent (Tyndale-Biscoe, 1996). In the USA there is a similar program for evaluating the potential of foreign species possibly useful in horn fly control, including Histeridae species (Fincher, 1995). This author also reports an efficiency evaluation of the predation effects of Hister bruchi, a specie imported from Argentina that acts mainly on maggot and pupa of $H$. irritans.

With regard to predation of these coleopterans on fauna associated with bovine feces, available information in South America is still meager. Most existent reports concentrate on the initial stage: determination of the species present in feces (Flechtmann et al., 1995a, b, and c; Cabrera-Walsh \& Cordo, 1997; Rodrigues \& Marchini, 1998; Koller et al., 1999).

This research was carried out to determine the local histerid fimicolous species as well the relative abundance of each specie, and respective population dynamic. Such information would be useful to identify species potentially important in bovine parasite control.

\section{MATERIAL AND METHODS}

The experiment was carried out in the $\mathrm{Na}$ tional Center of Beef Cattle Research (Embrapa Gado de Corte), part of the Brasilian Enterprise for Farming and Cattle-Raising Research (Embrapa), in Campo Grande, Mato Grosso do Sul State, Brazil (20²7' S and 54 $37^{\prime} \mathrm{W}$; Alt. $530 \mathrm{~m}$ ), from May 1990 to April 1992. This area is situated on the transition band of a wet mesothermical climatologic region (Cfa), with more than $30 \mathrm{~mm}$ of rain in the driest month, and the wet tropical region (Aw), with summer rainy season and winter dry season (Ometto, 1981). The pasture area (20 ha), predominantly of Brachiaria decumbens Stapf grass, was under permanent use with Nelore cattle (Bos taurus indicus).

Weekly between 8 and 9 a.m. three fecal masses (FM) were collected and brought to the laboratory. They showed humid to almost dry texture, as classified by Ávila \& Fernández-Sigler (1988), or with ages two and/or three, as classified by Flechtmann et al. (1995c).

The FM were conditioned in 15-liter opaque plastic buckets with covers, measuring $20 \mathrm{~cm}$ of the base diameter and $30 \mathrm{~cm}$ of the top opening. The buckets contained an $8 \mathrm{~cm}$ layer of soil. A lateral opening was made on the top level of the soil layer, with a second opening on the top of the bucket cover. In those openings, dry flasks were positioned to capture the insects present in the FM.

The FM were maintained in the buckets for 40 days and the insects retained in the capture flasks were picked up twice a week. After that period, the soil and FM residue were removed from the buckets and remaining live or dead insects collected. The adult insects obtained were conditioned in flasks containing $70 \%$ alcohol until being identified.

The collection data were analyzed utilizing abundance, frequency, constancy, together with fauna diversity indexes (Silveira-Neto et al., 1976).

\section{RESULTS}

Three thousand two hundred ninety-nine specimens of Histeridae coleopterans were collected, belonging to 11 species in the Genus Phelister, Hister, Euspilotus, Acritus, and Xerosaprinus (Table 1).

The two species that presented, on a decreasing scale, highest values abundance, constancy, and frequency indexes were Phelister sp. nr. carinifrons, and $P$. haemorrhous.

In relation to the abundance index (SilveiraNeto et al., 1976) the species Phelister rufinotus, Hister sp., Euspilotus erythropterus, H. punctifer, Acritus sp., Xerosaprinus sp. nr. lubricus, and E. 
pavidus were classified as common (Table 1). The species Phelister sp., and Euspilotus nigrita were classified as dispersed (Table 1).

The larger population levels of Histeridae were observed from October to May (Table 2; Fig.
1). That corresponds to the rainy season, and the annual period of higher average temperatures (October to April), except for May, which begins, in the study area, the dry season of the year (May to September) (Fig. 1).

TABLE 1

Some ecological indexes of the fimicolous Histeridae coleopterans species collected in Campo Grande, Mato Grosso do Sul, Brazil, from May 1990 to April 1992.

\begin{tabular}{|c|c|c|c|c|c|c|c|}
\hline \multirow{2}{*}{ Spp } & \multicolumn{2}{|c|}{ Abundance } & \multicolumn{2}{|c|}{ Constancy } & \multicolumn{2}{|c|}{ Frequency } & \multirow{2}{*}{ Total } \\
\hline & Year I & Year II & Year I & Year II & Year I & Year II & \\
\hline 01 & $\mathrm{va}^{2}$ & va & 84.62 & 67.92 & 36.2422 & 46.7236 & 1,306 \\
\hline 02 & va & $\mathrm{c}$ & 78.85 & 50.94 & 33.7489 & 16.3343 & 930 \\
\hline 03 & $\mathrm{c}$ & $\mathrm{c}$ & 61.54 & 49.06 & 12.7337 & 8.6420 & 377 \\
\hline 04 & $\mathrm{c}$ & $\mathrm{c}$ & 59.62 & 49.06 & 8.2369 & 16.9991 & 364 \\
\hline 05 & $\mathrm{c}$ & $\mathrm{c}$ & 19.23 & 28.30 & 1.8255 & 4.1785 & 85 \\
\hline 06 & $\mathrm{c}$ & $\mathrm{c}$ & 23.07 & 13.20 & 2.2262 & 2.5641 & 77 \\
\hline 07 & $\mathrm{c}$ & $\mathrm{c}$ & 21.15 & 20.75 & 1.6028 & 3.4188 & 72 \\
\hline 08 & $\mathrm{c}$ & - & 7.69 & - & 2.0036 & - & 45 \\
\hline 09 & $\mathrm{c}$ & $\mathrm{c}$ & 13.46 & 9.43 & 1.2467 & 1.1396 & 40 \\
\hline 10 & d & - & 1.92 & - & 0.0891 & - & 2 \\
\hline 11 & d & - & 1.92 & - & 0.0445 & - & 1 \\
\hline Total & & & & & & & 3,299 \\
\hline
\end{tabular}

${ }^{1}$ Spp (Species): 01 - Phelister sp. nr. carinifrons, 02 - P. haemorrhous, 03 - P. rufinotus, $04-$ Hister $\mathrm{sp} ., 05-$ Euspilotus erythropterus, 06 - H. punctifer, 07 - Acritus sp., 08 - Xerosaprinus sp. nr. lubricus, 09 - E. pavidus, 10 - Phelister sp., $11-$ E. nigrita.

${ }^{2} \mathrm{va}=$ very abundant; $\mathrm{c}=$ common; $\mathrm{d}=$ disperse.

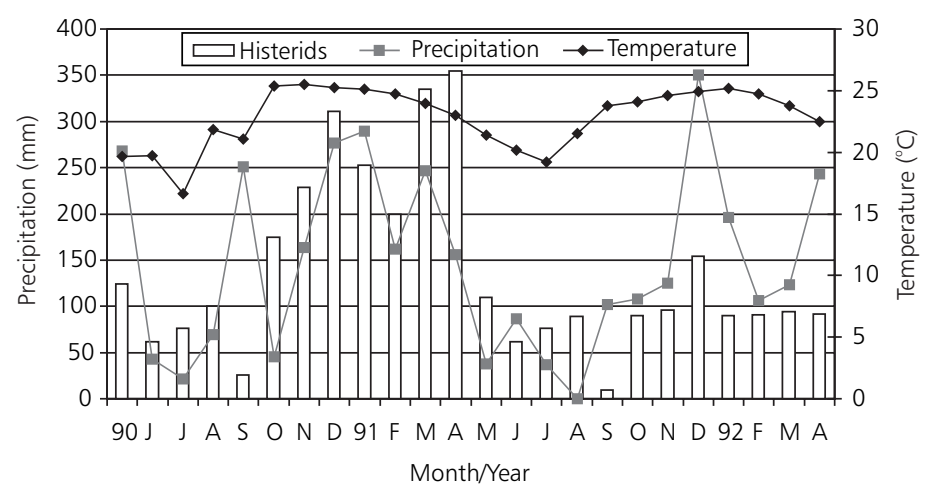

Fig. 1 - Monthly total of specimens of histerids captured, and meteorological records (total monthly precipitation and average temperature) in Campo Grande, Mato Grosso do Sul State, Brazil, from May 1990 to April 1992. 
TABLE 2

Monthly distribution of the fimicolous Histeridae coleopterans species collected in Campo Grande, Mato Grosso do Sul, Brazil, from May 1990 to April 1992.

\begin{tabular}{|c|c|c|c|c|c|c|c|c|c|c|c|c|c|}
\hline \multirow{2}{*}{ Spp } & \multirow{2}{*}{ Year } & \multicolumn{12}{|c|}{ Months } \\
\hline & & $\mathbf{M}$ & $\mathbf{J}$ & $\mathbf{J}$ & $\mathbf{A}$ & $\mathbf{S}$ & O & $\mathbf{N}$ & D & $\mathbf{J}$ & $\mathbf{F}$ & $\mathbf{M}$ & $\mathbf{A}$ \\
\hline \multirow[t]{2}{*}{01} & 1 & 37 & 44 & 62 & 76 & 13 & 22 & 45 & 73 & 74 & 98 & 136 & 134 \\
\hline & 2 & 67 & 34 & 46 & 60 & 6 & 19 & 32 & 61 & 73 & 33 & 19 & 42 \\
\hline \multirow[t]{2}{*}{02} & 1 & 22 & 8 & 3 & 11 & 6 & 104 & 81 & 82 & 112 & 55 & 140 & 134 \\
\hline & 2 & 22 & 16 & 17 & 11 & 2 & 5 & 15 & 18 & 3 & 11 & 32 & 20 \\
\hline \multirow[t]{2}{*}{03} & 1 & 51 & 0 & 1 & 5 & 3 & 39 & 57 & 53 & 18 & 24 & 11 & 24 \\
\hline & 2 & 9 & 8 & 5 & 15 & 0 & 15 & 15 & 11 & 2 & 6 & 5 & 0 \\
\hline \multirow[t]{2}{*}{04} & 1 & 14 & 10 & 10 & 2 & 0 & 3 & 7 & 52 & 23 & 19 & 26 & 19 \\
\hline & 2 & 11 & 4 & 7 & 1 & 0 & 34 & 15 & 41 & 11 & 6 & 22 & 27 \\
\hline \multirow[t]{2}{*}{05} & 1 & 0 & 0 & 0 & 0 & 3 & 1 & 14 & 14 & 8 & 0 & 1 & 0 \\
\hline & 2 & 0 & 0 & 1 & 0 & 1 & 10 & 12 & 11 & 1 & 3 & 3 & 2 \\
\hline \multirow[t]{2}{*}{06} & 1 & 0 & 0 & 0 & 0 & 0 & 0 & 0 & 20 & 11 & 3 & 7 & 9 \\
\hline & 2 & 1 & 0 & 0 & 0 & 0 & 0 & 0 & 0 & 0 & 19 & 6 & 1 \\
\hline \multirow[t]{2}{*}{07} & 1 & 0 & 0 & 0 & 0 & 1 & 4 & 8 & 6 & 3 & 0 & 10 & 4 \\
\hline & 2 & 0 & 0 & 0 & 2 & 0 & 2 & 2 & 10 & 0 & 13 & 7 & 0 \\
\hline \multirow[t]{2}{*}{08} & 1 & 0 & 0 & 0 & 6 & 0 & 0 & 0 & 6 & 0 & 0 & 2 & 31 \\
\hline & 2 & 0 & 0 & 0 & 0 & 0 & 0 & 0 & 0 & 0 & 0 & 0 & 0 \\
\hline \multirow[t]{2}{*}{09} & 1 & 0 & 0 & 0 & 0 & 0 & 2 & 16 & 5 & 4 & 1 & 0 & 0 \\
\hline & 2 & 0 & 0 & 0 & 0 & 0 & 5 & 5 & 2 & 0 & 0 & 0 & 0 \\
\hline \multirow[t]{2}{*}{10} & 1 & 0 & 0 & 0 & 0 & 0 & 0 & 0 & 0 & 0 & 0 & 2 & 0 \\
\hline & 2 & 0 & 0 & 0 & 0 & 0 & 0 & 0 & 0 & 0 & 0 & 0 & 0 \\
\hline \multirow[t]{2}{*}{11} & 1 & 0 & 0 & 0 & 0 & 0 & 0 & 1 & 0 & 0 & 0 & 0 & 0 \\
\hline & 2 & 0 & 0 & 0 & 0 & 0 & 0 & 0 & 0 & 0 & 0 & 0 & 0 \\
\hline \multicolumn{2}{|c|}{ Total } & 234 & 124 & 152 & 189 & 35 & 265 & 325 & 465 & 343 & 291 & 429 & 447 \\
\hline
\end{tabular}

${ }^{1}$ Spp (Species): 01 - Phelister sp. nr. carinifrons, 02 - P. haemorrhous, 03 - P. rufinotus, $04-$ Hister sp., $05-$ Euspilotus erythropterus, 06 - H. punctifer, 07 - Acritus sp., 08 - Xerosaprinus sp. nr. lubricus, 09 Euspilotus pavidus, 10 - Phelister sp., 11 - Euspilotus nigrita.

\section{DISCUSSION}

The richness of Histeridae species found was greater than that verified by Flechtmann et al. (1995c) in Selvíria, Mato Grosso do Sul (six spp.); Flechtmann et al. (1995a) in Ilha Solteira, São Paulo (eight spp.); Rodrigues \& Marchini (1998) in Piracicaba, São Paulo (four spp.); and CabreraWalsh \& Cordo (1997) in Argentina (six spp.).

The results showed that Phelister sp. nr. carinifrons and $P$. haemorrhous had the largest abundance, constancy, and frequency indexes, which should be considered in either a control program or integrated management of bovine parasites associated with bovine feces.

In the first year of this experiment, the histerid population was higher than in the second year, and the population level showed a tendency to follow precipitation (Fig. 1). Thus, the lower number of histerids in the second year would result from less rain.

The period from June to September corresponds in the study area to the driest period of the year, at which time native species of observed Histeridae show reduced their population levels, which drastically decreases predation activities. 
Thus, species with less moisture dependence, among other characteristics, constitute preferential candidates in programs of Histeridae introduction which seek to further biological control of pests associated with bovine feces. Identifying ecological parameters of the most numerous local species may help in making decisions on introducing other species. This will contribute to natural control of these pests in periods when native histerids become rare.

Recently, several authors (Fincher, 1992; McCracken, 1993; Wiktelius, 1996; Bianchin et al., 1997, 1998) have called attention to the presence of pesticides in fecal residues of treated animals. Such residue act deleteriously on fimicolous organisms, possibly causing mortality among useful biological control agents. The frequent exposure of their enemies to residue or to low concentrations of the pesticides designed to eliminate them, as is happening in the case of bovine feces, contributes to the process of selection of individuals resistant to such products.

Global attention is gradually the awakening to the importance of reducing, to the minimum possible, pesticide use and residual levels acceptable in foodstuff so as to protect the environment and food supply. Additional pressure has been exercised by the high costs associated with pesticide use. Therefore, research must address identification and adoption of integrated pest management practices, including control of organisms considered pests through the use of their natural enemies or competitors.

Acknowledgment — To Drs. Cleber Oliveira Soares (Embrapa Gado de Corte Consultant), and Raul Henrique Kessler (Embrapa Gado de Corte Researcher) for suggestions on the manuscript.

\section{REFERENCES}

ARNETT Jr., R. H., 1968, The beetles of the United States. Ann Arbor, The American Entomological Institute, pp. 369-384.

ÁVILA, J. M. \& FERNÁNDEZ-SIGLER, A., 1988, Influencia de la textura del excremento en la distribución y abundancia de algunas especies de escarabeidos coprófagos en el sur de la península Ibérica (Coleoptera: Scarabaeoidea). Elytron, 2: 27-35

AXTELL, R. C., 1986, Fly management in poultry production cultural, biological and chemical. Poultry Sci., 65: 657-667.

BIANCHIN, I., ALVES, R. G. O. \& KOLLER, W. W., 1997, Efeito de carrapaticidas/inseticidas aspersão sobre adultos do besouro coprófago africano Onthophagus gazella (F.). Ecossis., 22: 116-119.
BIANCHIN, I., ALVES, R. G. O. \& KOLLER, W. W., 1998, Efeito de carrapaticidas/inseticidas "pour-on" sobre adultos do besouro coprófago africano Onthophagus gazella Fabr. (Coleoptera: Scarabaeidae). An. Soc. Entomol. Brasil, 27: 275-279.

BULL, D. L., HARRIS, R. L. \& PRYOR, N. W., 1988, The contribution of metabolism to pyrethroid and DDT resistance in the horn fly (Diptera: Muscidae). J. Econ. Entomol., 81: 449-458.

CABRERA-WALSH, G. \& CORDO, H. A., 1997, Coprophilous arthropod community from Argentina species of potential use as biocontrol agents against pest flies. Environ. Entomol., 26: 191-200.

CILEK, J. E., DAHLMAN, D. L. \& KNAPP, F., 1995, Possible mechanism of diazinon negative cross-resistance in pyrethroid-resistant horn flies (Diptera: Muscidae). J. Econ. Entomol., 88: 520-524.

FINCHER, G. T., 1992, Injectable ivermectin for cattle: effects on some dung-inhabiting insects. Environ. Entomol., 24: $871-876$.

FINCHER, G. T., 1995, Predation on the horn fly by Hister bruchi. Southwest. Entomol., 20: 423-427.

FLECHTMANN, C. A. H., RODRIGUES, S. R., ARAÚJO, S. D. \& WENZEL, R. L., 1995a, Levantamento de insetos fimícolas em Ilha Solteira, São Paulo, Brasil. Rev. Bras. Entomol., 39: 115-120.

FLECHTMANN, C. A. H., RODRIGUES, S. R. \& SENO, M. C. Z., 1995b, Controle biológico da mosca-dos-chifres (Haematobia irritans irritans) em Selvíria, Mato Grosso do Sul. 3. Levantamento de espécies fimícolas associadas à mosca. Rev. Bras. Entomol., 39: 249-258.

FLECHTMANN, C. A. H., RODRIGUES, S. R. \& GASPARETO, C. L., 1995c, Controle biológico da mosca-dos-chifres (Haematobia irritans irritans) em Selvíria, Mato Grosso do Sul. 6. Dinâmica populacional de insetos fimícolas excetuando-se Scarabaeidae coprófagos. Rev. Bras. Entomol., 39: 287-296.

GEDEN, C. J. \& AXTELL, R. C., 1988, Predation by Carcinops pumilio (Coleoptera: Histeridae) and Macrocheles muscaedomesticae (Acarina: Macrochelidae) on the housefly (Diptera: Muscidae): functional response effects of temperature, and availability of alternative prey. Environ. Entomol., 17: 739-744.

GREENBERG, B., 1971, Flies and diseases; ecology, classifications and biotic associations. Princeton University Press, Princeton, 856p.

KOLlER, W. W., GOMES, A., RODRIGUES, S. R., RODRIGUES, A. C. L., PENTEADO-DIAS, A. M. \& MENDES, J., 1999, Staphylinidae, Histeridae (Coleoptera) e Hymenoptera fimícolas do Cerrado Sul-mato-grossense. In: Mostra Uniderp de Ciência e Tecnologia. Anais, UNIDERP/Fundação Manoel de Barros, Campo Grande, pp. 117-119.

LINHARES, A. X., 1981, Synantropy of Calliphoridae and Sarcophagidae (Diptera) in the City of Campinas, São Paulo, Brazil. Rev. Bras. Entomol., 25: 189-215.

LOMÔNACO, C. \& ALMEIDA, J. R. D., 1995, Muscoid Diptera community structure of Jacarepagua sand dunes, Rio de Janeiro, Brazil. Rev. Bras. Entomol., 39: 891-896. 
McCRACKEN, D. I., 1993, The potential for avermectins to affect wildlife. Vet. Parasitol., 48: 273-280.

McKENZIE, C. L. \& BYFORD, R. L., 1993, Continuous, alternating, and mixed insecticides affect development of resistance in the horn fly (Diptera: Muscidae). J. Econ. Entomol., 86: 1040-1048.

OMETTO, J. C., 1981, Bioclimatologia vegetal. São Paulo, Agronômica CERES, 425p.

RODRIGUES, S. R. \& MARCHINI, L. C., 1998, Espécies de Histeridae coletadas em Piracicaba, SP. Sci. Agric. 55: 59-63.

SHEPPARD, D. C., 1995, Oxidative metabolic resistance to cyanopyrethroids in the horn fly (Diptera: Muscidae). $J$. Econ. Entomol., 88: 1531-1535.

SILVEIRA-NETO, S., NAKANO, O., BARBIN, D. \& NOVA, N. A. V., 1976, Manual de ecologia de insetos. Ed. São Paulo, Agronômica CERES, 419p.
SUMMERLIN, J. W., ROTH, J. P. \& FINCHER, G. T., 1991, Predation by two species of histerid beetles on the horn fly. Southwest. Entomol., 16: 45-49.

TYNDALE-BISCOE, M., 1996, Australia's introduced dung beetles: original releases and redistributions. Technical Report CSIRO Division of Entomology, 62: iv + 149p.

ZIZAK, M. D., BYFORD, R. L., CRAIG, M. E. \& LOCKWOOD, J. A., 1996, Behavioural responses of the horn fly (Diptera: Muscidae) to select insecticides in contact and noncontact environments. Environ. Entomol., 25: 120-129.

WIKTELIUS, S., 1996, Environmental effects of the use of ivermectin. Sven. Veterinart., 48: 653-658. 